
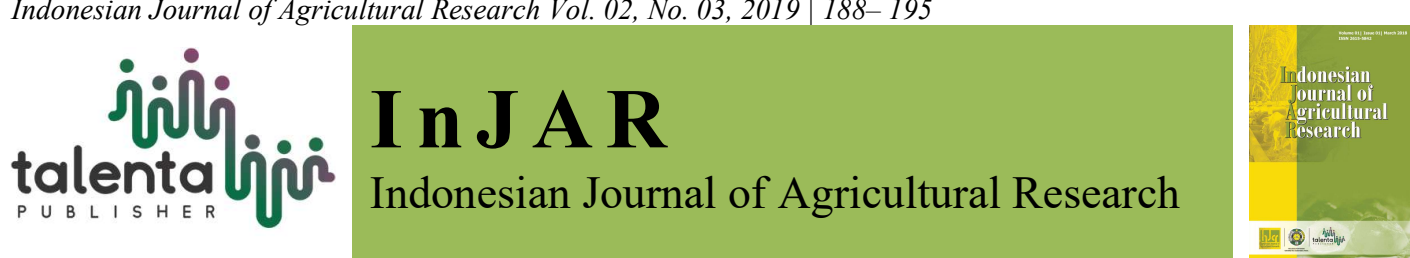

\title{
Physical and Organoleptic Quality of Culled Layers Chicken Meat Using Marinated Asam Kandis Fruits (Garcinia dioica Blume)
}

\section{Peni Patriani* and Tri Hesti Wahyuni}

Animal Husbandry Study Program, Faculty of Agriculture, Universitas Sumatera Utara, Indonesia

\begin{abstract}
Asam Kandis is one of the fruits with a sour taste that is often used in the spice. Asam Kandis is very effective as a food flavoring such as in meat and fish. Culled layers meat usually has a rough texture, tough and not preferred because it has a rough tenderness, so it needs natural herbs to improve tenderness or maintain the physical. This study uses a completely randomized design with 4 treatments and 4 replications. The treatment in this study marinated culled layers chicken in Asam Kandis consisting of 4 levels: $0 \%, 5 \%, 10 \%$, and $15 \%$. Research aimed to improve the physical and organoleptic quality of culled layers of chicken meat using Asam Kandis. The results obtained physical and organoleptic quality in culled layers chicken meat, which includes $\mathrm{pH}$, drip loss, and tenderness, significantly affect the marinated Asam Kandis. Water content and cooking losses do not affect the marination of Asam Kandis and are quite effective. Conclusion in this research Asam Kais has a quite good effect on improving the quality of culled layers of chicken meat. It is recommended marination using Asam Kandis with a level of $9 \%$ effective maintain the quality of culled layers meat.
\end{abstract}

Keywords: asam kandis, culled layers chicken meat, marinated, organoleptic, physical quality

Received 10 December 2019 | Revised 06 January 2020 | Accepted 27 February 2020

\section{Introduction}

Asam Kandis is one of the fruits with a sour taste that is often used as a spice in Sumatra. Asam Kandis is often using as a flavoring dish by thinly sliced, which was previously dried first. Asam Kandis fruit is very effective as a food flavoring such as in meat and fish. Culled layers chicken usually have a rough texture. [1] that the level of meat roughness or texture in meat has increased in line with age. The level of meat toughness is also influenced by collagen, which is a structural protein in connective tissue while the number of colleges will increase with age; this is the cause of meat toughness.

\footnotetext{
*Corresponding author at: Animal Husbandry Study Program, Faculty of Agriculture, Universitas Sumatera Utara, Jl. Prof. Sofyan No. 3, Medan 20155, Indonesia

E-mail address: ppatriani@gmail.com
} 
Asam Kandis fruit contains organic acids such as hydroxy citric acid and ascorbic acid, some organic and phenolic acids [2]. The addition of acid when done to meat causes denaturation of proteins, thereby breaking down polypeptide bonds and changing the composition of proteins so that the meat is very soft. [3] have shown Asam Kandis fruit also has anti-bacterial activity, including Salmonella sp. Asam Kandis fruit is also known to have antimicrobial and antioxidant activity [4].

Asam Kandis fruit also has phenolytic compounds, flavonoids, alkaloids, and saponins [5] the presence of these compounds also acts as an antioxidant. [5] examined that Asam Kandis can inhibit spoilage bacteria in Nila fish. In addition to containing anti-microbial, Asam Kandis also contains citric acid so that Asam Kandis has the potential as a culled layer chicken. Marination is a method of processing foods that aims to preserve and flavor, retain juicily, and increase meat tenderness and improve texture. Marination using acidic substances aims to tenderness meat because it has the effect of cutting meat fibers in addition to inhibiting spoilage microbes in food. The purpose of this research was to determine the effect of Asam Kandis levels on physical and organoleptic quality in layers of chicken meat.

\section{Materials and Methods}

The materials used in this study were 250-gram Asam Kandis [Figure 1], aqua dest, culled layers chicken 1500 grams. The experiment was a completely randomized design with 4 replications. The treatment for this determination was the marinated of culled layers chicken meat in a solution of Asam Kandis consisting of 4 levels: $0 \%, 5 \%, 10 \%$, and $15 \%$.

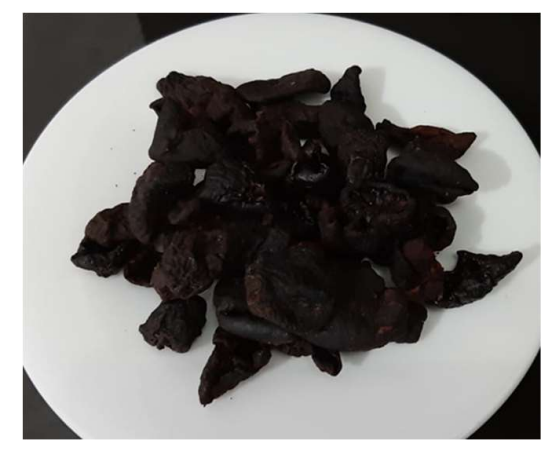

Figure 1. Asam Kandis (Garcinia dioica Blume) After Drying

Asam Kandis is mashed and then filtered, then culled layers chicken meat is separated with bone or deboning then marinated on an extra 30-minute in Asam Kandis [6]. The parameters in this study were meat $\mathrm{pH}$, cooking loss, drip loss, Postma test, and meat texture (organoleptic). Organoleptic calculation using the following score. 
Table 1. Organoleptic Testing of Meat Tenderness

\begin{tabular}{cc}
\hline Score & Tenderness \\
\hline 5 & Very tenderness \\
4 & Tenderness \\
3 & Rather tenderness \\
2 & Tough \\
1 & Extreme Tough \\
\hline
\end{tabular}

The $\mathrm{pH}$ value of meat was measured using a $\mathrm{pH}$ meter [7] [8] ie, meat that had been marination using Asam Kandis weighed 5 grams, then blended for 1 minute and added to $10 \mathrm{ml}$ of distilled water. Cooking loss is made using the CSIRO method, Drip loss using the plastic bag method and tenderness texture using organoleptic [9].

Data were analyzed using analysis of variance (ANOVA) [10]. If the effect of the treatment was significantly different at the $0.05 \%$ and $0.01 \%$ levels followed by the LSD test or the smallest significant difference test to determine the best levels Asam Kandis fruit marination. The study conducted in May 2019 at the Laboratory of Animal Husbandry, Faculty of Agriculture, and MIPA Organic Chemistry Laboratory.

\section{Results and Discussion}

Results can be presented in figures and Tables 2 . The results showed that the quality of the layers chicken meat after treatment using marinated Asam Kandis $0 \%, 5 \%, 10 \%$ and $15 \%$ on the physical and organoleptic quality of the layers chicken meat was as follows:

Table 2. Quality of Culled Layer Chicken Meat with Marinated Asam Kandis

\begin{tabular}{ccccc}
\hline \multirow{2}{*}{ Level } & \multicolumn{4}{c}{ Physical Quality of culled layer chicken meat with marinated Asam Kandis } \\
\cline { 2 - 5 } & $\mathbf{p H}$ & Cooking loss (\%) & Drip loss (\%) & Water content (\%) \\
\hline $\mathrm{P} 0=0 \%$ & $5.87 \pm 0,6^{\mathrm{a}}$ & $27 \pm 5.2$ & $3.9 \pm 2.2^{\mathrm{a}}$ & $75 \pm 2.2$ \\
$\mathrm{P} 1=5 \%$ & $5.76 \pm 0.4^{\mathrm{a}}$ & $30 \pm 3.4$ & $4.2 \pm 1.5^{\mathrm{a}}$ & $75 \pm 4.5$ \\
$\mathrm{P} 2=10 \%$ & $5.70 \pm 0.3^{\mathrm{ab}}$ & $30 \pm 3.5$ & $3.7 \pm 1.2^{\mathrm{ab}}$ & $77 \pm 3.0$ \\
$\mathrm{P} 3=15 \%$ & $5.60 \pm 0.3^{\mathrm{b}}$ & $32 \pm 4.6$ & $2.1 \pm 1.8^{\mathrm{b}}$ & $79 \pm 3.6$ \\
\hline
\end{tabular}

\subsection{Meat $\mathrm{pH}$ Value}

Based on the results in Table 2, the highest average $\mathrm{pH}$ value in culled layers chicken is $\mathrm{P} 0$ or control, which is 5.87, and the lowest is P3 or marinated 15\% Asam Kandis which is 5.60. The results of the analysis of variance showed that there was a real treatment effect $(\mathrm{P}<0.05)$. This shows the $\mathrm{pH}$ value decreases according to the level of administration of Asam Kandis. Asam Kandis has an acidic $\mathrm{pH}$ which is thought to cause an increase in acidity and cause a $\mathrm{pH}$ reduction in meat. BNT test results showed that the $\mathrm{pH}$ value at $15 \%$ treatment was significantly different and lower when compared to $0 \%, 5 \%$, and $10 \%$ treatments. Normal meat $\mathrm{pH}$ has a value of 5.4 to $5.8[10]$. 


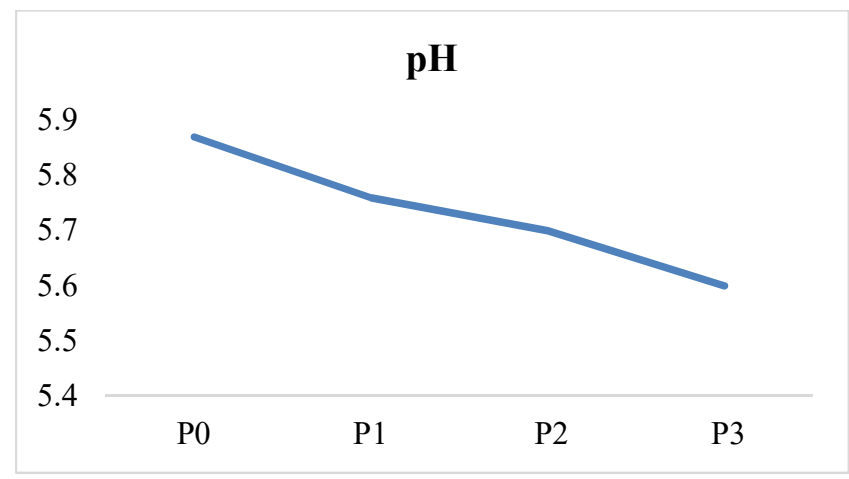

Figure 2. pH of Marinated Culled Layers Chicken

[11] states glycogen in meat aerobically undergoes glycolysis so that lactic acid is product gradually so that the $\mathrm{pH}$ decreases. After glycogen reserves are exhausted, glycogen is separated into lactic acid, causing the $\mathrm{pH}$ of the meat to rise gradually due to the process of autolysis of proteins by microbes. The $\mathrm{pH}$ value of the meat decreases with an increasing level of Asam Kandis is thought to be caused by protein hydrolysis of the culled layers of chicken meat. The higher the level of Asam Kandis marination will reduce the $\mathrm{pH}$ of chicken meat and influence the acidity. The $\mathrm{pH}$ value in this study belongs to a good range [10], that the $\mathrm{pH}$ value in meat ranges typically from 5.4 to 5.8 .

\subsection{Cooking Loss}

The percentage of cooking loss is the weight of meat lost during the cooking process. The results showed that cooking losses were not significantly different $(\mathrm{P}>0.05)$ in the treatment of Asam Kandis marination. The results of observations in the study, the highest value of cooking loss in culled layer chicken meat after the marinating acid in control (P3) was 32\%, and the lowest cooking losses were $0 \%(\mathrm{P} 0)$ at $27 \%$.

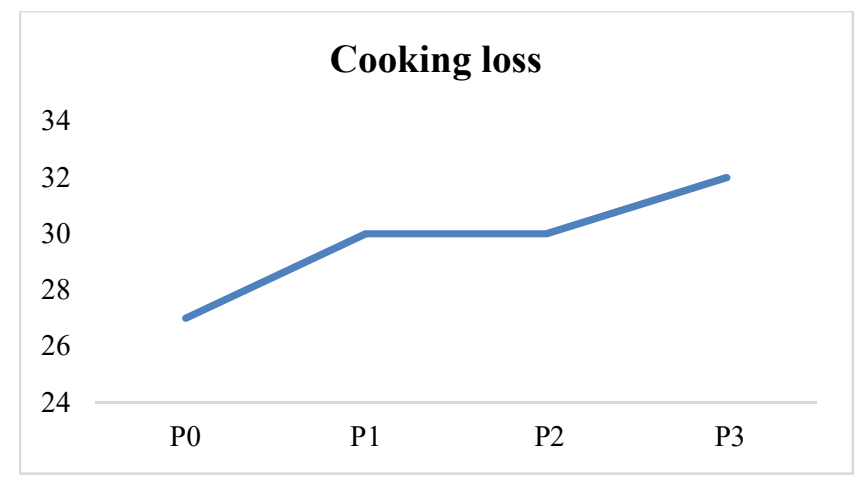

Figure 3. Cooking loss in marinated culled layer meat

It is suspect that the more the level of Asam Kandis, the more fat dissolve so that it can reduce the value of cooking losses [12] soaking pineapple on layers ducks can reduce cooking losses because it can dissolve fat so that it will reduce the value of the cooking loss [13] that the high value of cooking losses is associated with muscle fibers and collagen tissue shrinkage. The value 
of cooking shrinkage in this study is still in the normal category in line with [14] that the value of cooking loss in standard meat ranges from $15 \%$ to $40 \%$.

\subsection{Drip Loss}

Drip loss is moist meat that comes out with nutrients of the meat that dissolve and disappear. If the meat experiences a rapid decrease in $\mathrm{pH}$, it can cause the surface of the meat to become wet, which is marked by the discharge of the surface of the meat (drip) [15] state that drip loss can measure on all pieces or parts of pieces. The value of drip loss in the study was significantly different $(\mathrm{P}<0.05)$ in the treatment of Asam Kandis marination. The highest drip loss value is at $5 \%(\mathrm{P} 1)$, followed by control (P) and $10 \%(\mathrm{P} 2)$, while the lowest is at $15 \%(\mathrm{P} 3)$.

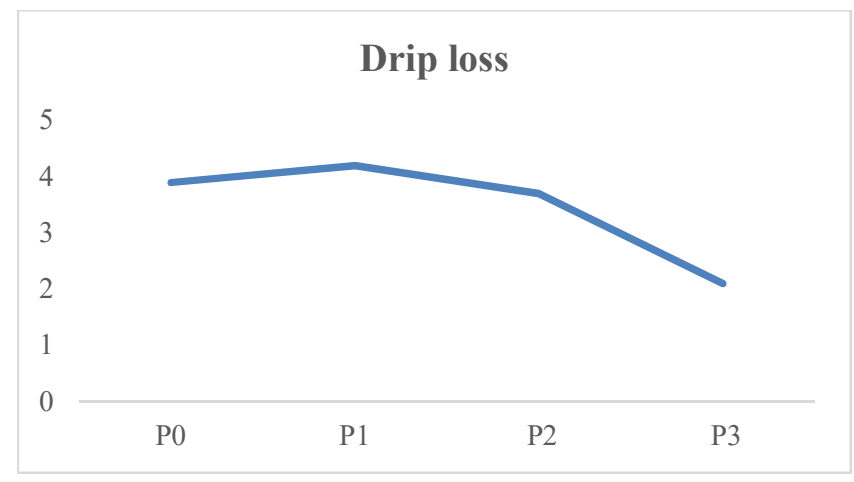

Figure 4. Drip Loss in Marinated Culled Layer Meat

[16] showed the drip loss at pork $4.4 \%$ of carcass weight. The more fatty food will increase the value of drip loss. Drip loss in the study is still at an average level, but the drip loss value in the study decreased at 15\% Asam Kandis marinated (P3). Estimated that marinating for 30 minutes can suppress the release of drip or nutrients in meat. The drip loss in the study is lower than that reported by [17] that the drip loss in lamb is $10.2 \%$. Overall, the value of drip loss in this study is still in a reasonable range.

\subsection{Water Content}

The water content of culled layers of chicken meat that marinate using Asam Kandis was not significantly different $(\mathrm{P}>0.05)$. The highest water content in the study was at $15 \%$ (P3) at $79 \%$, while the lowest was at control (P0) at 75\% and 5\% (P1) at 75\%. Asam Kandis does not affect water content because the ability of culled layers chicken meat to absorb the Asam Kandis marinated liquid around it in saturated conditions. It suspected that the condition of the culled layers chicken could not absorb more water.

According to [12], the water content of duck meat in soaking pineapple for 30 minutes ranged from $65.57 \%$ to $63.38 \%$. Some factors that affect the water content of meat include the age of livestock. [18] in the study used laying hens that were 24 months old so that in terms of age 
included in the old category. Added by [18], water levels can decrease with increasing age in livestock; on the contrary fat content can increase when cattle mature.

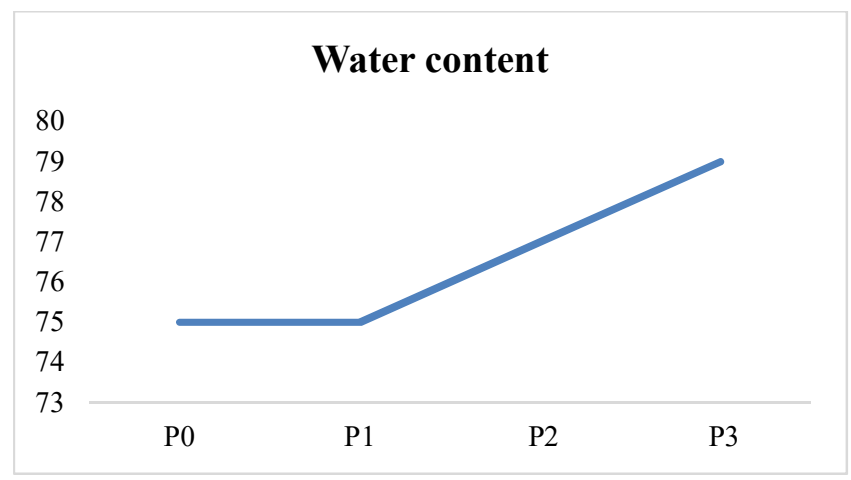

Figure 5. Water Content in Marinated Culled Layer Meat

Marinating the culled layer meat in Asam Kandis using liquid media can also cause high water content because some of the water will seep on the surface of the meat so that it affects the water content even though the presentation is only slightly. Standard chicken water content, according to [19], ranged from $65 \%-80 \%$ so that the water content of meat in the study included in the category which is quite good. Water content in the study ranged from $75 \%$ to $79 \%$ in the normal category.

\subsection{Tenderness}

Organoleptic assessment results obtained for meat testing using organoleptic tests performed on trained panelists after processing in Table 3 .

Table 3. Organoleptic Tests in Marinated Culled Layer Chicken Meat

\begin{tabular}{cc}
\hline Level Asam Kandis & Tenderness \\
\hline P0 & $3.67^{\mathrm{a}}$ \\
P1 & $3.73^{\mathrm{a}}$ \\
P2 & $3.87^{\mathrm{ab}}$ \\
P3 & $4.67^{\mathrm{b}}$ \\
\hline
\end{tabular}

The highest tenderness in chicken meat on marination with Asam Kandis level 15\% (P3) has a value of 4.67 , continues to decline to a level of $10 \%(\mathrm{P} 2)$ with a value of 3.87 while at the level of 5\% (P1) 3.73 decreases back to control or without treatment ie, 3.67 (P0). In the study, the highest value was obtained in $\mathrm{P} 3$ with the inferred category, whereas in P2, P1, and P0, it includes in the subtle. It means that Asam Kandis marination can make a lot, and the rough texture of the culled layer chicken meat softer and smoother. Directly organoleptic assessments were carried out by the best panelists on P3. The tenderness of the meat after the Asam Kandis marination will be softer because Collagen and myofibrils are hydrolyzed and cause shorter flesh fibers and muscle fibers to be easily separated so that meat tenderness can increase. 


\section{Conclusion and Recommendation}

Asam Kandis marination has an excellent effect on improving the quality of the culled layer chicken meat. It is recommended that marination using Asam Kandis with a level of $10 \%$ can effectively maintain the quality of culled layer chicken meat. In conclusion, Asam Kandis marination of $10 \%(\mathrm{P} 2)$ is the best level and effectively maintains the physical and organoleptic quality of Layers Chicken Meat.

\section{Acknowledgments}

Thank the research team and the Laboratory of Animal Husbandry, Universitas Sumatera Utara, and the parties involved in this research. Thanks also to the lecturers of animal husbandry study programs who provided direction and input in this study.

\section{REFERENCES}

[1] Soeparno, Ilmu dan Teknologi Daging [Meat science and technology]. Edisi 2. Gajahmada University Press, Yogyakarta, 2016.

[2] Cahyani, "Supplementation of Asam Kandis extract (Garnicia Xanthochimus) in drinking water against meat and quail eggs," Essay. Department of Nutrition and Feed Technology, Faculty of Animal Husbandry IPB, Bogor, 2018.

[3] N. Fitriana and A. Jayuska, "Antibacterial activity of ethanolic extract of Asam Kandis (Garcinia diocia Blume) which encapsulated maltodextrin," J Kimia Khatulistiwa vol. 3, no. 1, pp. 7-11, 2014.

[4] P Ardiningsih, Sumarni, R. Nofiani and A. Jayuska, "Phytochemical Screening and Antimicrobial Activity of Sub Fractions Asam Kandis (Garcinia diocia Blume)," J. of Applied Pharmaceutical Science, vol. 2, no. 12, pp. 172- 174, 2012.

[5] Rudiansah, "Preservation activity of Ethyl acetate fraction of Candis acid (G. Dioica Blum) Fruit on Freshness of Tilapia (Oreochromis niloticus)," Essay. 2012.

[6] E. Purnamasari, M. Zulfahmi, I. Mirdhayati, "The physical properties of the laying hens soaked in pineapple (Ananas comosus L. Merr) skin with different concentrations," Jurnal Peternakan vol 9, no 1, pp. 1-8, 2012.

[7] J. D. Merthayasa, I. K. Suada, K. K. Agustina, "Water binding capacity, pH, color, smell and texture of Bali beef and Wagyu beef," J. Indonesia Medicus veterinus vol. 4, no.1, pp.16-24, 2015.

[8] P. Patriani, H. Hafid, E. Mirwandhono, T.H. Wahyuni, "Kualitas daging domba dengan penerapan teknologi marinasi menggunakan kluwak fermentasi terhadap masa simpan [Quality of Mutton Meat With aplication of Marinated Technology Using kluwak Fermentationin the Shelf life]," Prosiding Seminar Nasional Teknologi Peternakan dan Veteriner. Teknologi Peternakan dan Veteriner Mendukung Kemandirian Pangan di Era Industri 4.0, pp.491-499, 2019.

[9] S.T. Soekarto, Organoleptic Assessment for Food Industry and Agricultural Products. Penerbit Bhatara Karya Aksara Jakarta, 1985.

[10] Soeparno, Meat science and technology. Cetakan ke -6 (edisi revisi). Gajah Mada University Press, Yogyakarta, 2015.

[11] S. Y. Setiawan, I. B. N. Swacita, I. K.Suada, "Beef quality in Pesanggaran Abbatoir rated from $\mathrm{pH}$ Value and water holding capacity" Bull Vet Udayana vol. 9, no. 1, pp.6-21, 2017. 
[12] R Novita, Sadjadi, T karyono dan R. Mulyono, "Level of pineapple extract (Ananas Comosus L. Merr) and soaking time on the quality of Culled duck meat," Jurnal Peternakan Indonesia, vol 21, no. 2, pp.143-153, 2019.

[13] E. M. E. Obuz, Dikeman, J.P. Grobel, W. Stephens and T. M. Loughin, "Beef longissimus lumborum, Biceps femoris, and deep Pectoralis warner blatzer force is affected differently by and point temperature, cooking method, and USDA quality grade," Meat sci, vol. 68, pp.243-248, 2004.

[14] R. A. Lawrie, Meat Science. Edition 5. Translated by A. Perakasi. UI Press, Jakarta, 2003.

[15] A.M. Pearson and T.R. Dutson, Quality attributes and their measurement in meat, poultry, and fish product. Blackie Academic and Professional, Inggris, 1994.

[16] C. O. Leskanich, K. R. Matthews, C. C. Warkup, R. C. Noble and M. Hazzledine, "The effect of dietary oil containing (n-3) fatty acids on the fatty acid, physicochemical, and organoleptic characteristics of pig meat and fat," J Anim Sci, vol. 75, pp.673-683, 1997.

[17] J. D. Kemp, D.G. Ely, J. D. Fox and W. G. Moody, "Carcass and Meat Characteristics of Crossbred Lambs with and without Finnish Landrace Breeding," J Anim Sci vol. 52, pp.10261033, 1981.

[18] D. H. Tilman, Hartadi, S Reksodiprojo, S. Prawirokusumo dan L. Lebdosoekojo, "Basic Animal Science. Gajah Mada University. Press Jogjakarta, 1989.

[19] J.C. Forrest, E. B. Aberle, H. B. Hedrick, M. D . Judge dan R. A . Merkel, Principles of Meat Science. W H. Freeman and Co, San Fransisco, 1975. 